\title{
The Marginalization of Secularism in the American Political Practice
}

\author{
Dr. Wassim Daghrir
}

\begin{abstract}
The religion-politics nexus marginalizes the secular and rational political message, which has a serious impact on the efficiency of American democracy. In fact, a well-functioning democracy is based on a large exchange of political ideas, not on simplistic faith-based preaches. Thus, the US Constitution, the pillar of the American political system, conditioned the well-functioning of democracy on the unambiguous separation between church and state. Yet, the American people's high religiosity has always been largely taken into consideration by major American politicians who have rarely resisted giving a religious orientation to their political message. Indeed, concepts such as "Chosen People", "City upon a Hill" (Colonial Era), "Manifest Destiny", "Divine Ordinance" (19 $9^{\text {th }}$.); “America's Mission”, and "American Exceptionalism" (Contemporary Era) have rarely been challenged in the mainstream political milieu, at the expense of the rational, secular perspectives.

Key Words: Religion-Politics Nexus / a Secular Democracy? / Religiosity / Religion and Politics / Religion and Foreign Policy / theoretical secularism vs. practical religiosity
\end{abstract}

\section{Introduction}

The religion-politics nexus marginalizes the secular and rational political message, which has a serious impact on the efficiency of American democracy. In fact, a healthy democracy is based on a large exchange of political ideas, not on simplistic faith-based preaches. Thus, the US Constitution, the pillar of the American political system, conditioned the well-functioning of democracy on the unambiguous separation between church and state. Yet, the American people's high religiosity has always been largely taken into consideration by major American politicians who have rarely resisted giving a religious orientation to their political message. Indeed, concepts such as "Chosen People", "City upon a Hill" (Colonial Era), "Manifest Destiny", "Divine Ordinance" $\left(19^{\text {th }}\right.$ c.), "America's Mission", and "American Exceptionalism" (Contemporary Era) have rarely been challenged in the mainstream political milieu, at the expense of the rational, secular perspectives.

\section{Secularism and the Constitution}

During the independence and foundation years, attitudes toward religion among the American elite experienced profound changes as a result of scientific rationalism and the Enlightenment thinking of the $18^{\text {th }}$ c. Indeed, the growing concern with "the laws of nature" as embodied by the discoveries of the English scientist Isaac Newton and the doctrines of the English philosopher John Locke helped shape a new understanding of religion and give further credit to the principle of religious liberty, symbolizing a shift from "an age of faith" to "an age of reason".

The strong emphasis on freedom of the mind which marked the Enlightenment Era had a far-reaching impact on the early American intellectual, social and political elite. Symbolically, some of those who contributed the most to the birth of the new American nation were also the ones who led the struggle for liberty of conscience and disestablishment. Indeed, Thomas Jefferson, the chief formulator of the Declaration of Independence, and James Madison, often referred to as the intellectual of the American Constitution, may just as well be remembered as apostles of religious freedom. In this vein, Madison advocated "free exercise" of religion as the natural right of every citizen; and Jefferson argued that "our civil rights have no dependence on our religious opinions, anymore than our opinions in physics or geometry."

The US Constitution embodied these revolutionary ideals in the form of its $6^{\text {th }}$ Article and its $1^{\text {st }}$ Amendment. Breaking with the Old World's tradition which had consistently linked public office to religious affiliation, Articles VI reads as follows: "no religious test shall ever be required as a qualification to any office or public trust under the US". The First Amendment declared that "congress shall make no law respecting an establishment of religion, or prohibiting the free exercise thereof". It, thus, guaranteed freedom of worship through separation of church and state. It guaranteed that the national government cannot impose any particular faith on the American people by law and that religious practice (or the absence of it) remains a matter of 
individual, private choice. For Thomas Jefferson, the First Amendment's provisions were intended "to build $\boldsymbol{a}$ wall of separation ${ }^{1}$ between church and state", which would prevent mutual interference.

\section{Religiosity in the US}

Alexis de Tocqueville wrote in 1835: "there is no country in the world where the Christian religion retains a greater influence over the souls of men than America". ${ }^{2}$ Today, the US is the most religious industrialized nation on earth. Actually, religious language, symbols and values play a considerable role in public discourse. Candidates are likely to invoke God in their campaigns and to make frequent statements to their own religious convictions.

The compatibility presumed to exist between Christianity and democracy has had implications not just for the American system of government but also for the public image of government officials. A candidate for the presidency or any high political position needs to comply with religious morality. In recent opinion polls, 72 $\%$ of Americans agreed with the statement that "the president should have strong religious beliefs". ${ }^{3}$ In March 2005, the House of Representatives Majority Leader Tom Delay stated that "there is no such thing, or no mention, of separation of church and state in the constitution" ". During the 2000 Presidential Campaign, Al Gore promised, if elected, to precede every major executive decision with the question 'what would Jesus do?' President George W. Bush out-faithed Gore by beginning each cabinet meeting with a prayer. ${ }^{5}$

In addition to the historical Puritanism, "City upon a Hill", "Manifest Destiny", "Divine Ordinance" and "Great Awakening" convictions, the vitality of American religion is largely the product of the country's diversity. In such a nation of immigrants, religion often functions as a much-needed source of identity. So, given ethnic variety, all faiths known to the world are represented in America. No less than 2000 denominations are said to find expression in the nearly 500000 churches, synagogues, mosques and temples in the nation. Recent surveys reveal that $94 \%$ of Americans attest to believe in god, that 7 out of 10 Americans are church members, and that 4 in 10 attend church or synagogue on a weekly basis. ${ }^{6}$

Among the other grounds for such high religiosity, besides the spiritual roots and the cultural diversity, one could refer to such factors as voluntary participation, existential insecurity, which provides a fertile ground for religion, religious propaganda via evangelical television, the power of money as well as the extreme devotion and organization of religious groups, such as the New Christian Right characterized by a strong commitment to political activism and lobbying reinforced by the movement's extreme organization, mass mobilization, and capacity for fund-raising.

\section{Religiosity's Impact on the Functioning of American Democracy}

The religion-politics nexus has had serious impact on the functioning of American democracy. The religion-politics entente marginalizes the secular and rational political message, which has a serious impact on the efficiency of American democracy. In fact, a healthy democracy is based on a large exchange of political ideas, not on simplistic faith-based preaches. But in a moralistic political scene characterized by a theoretical secularism vs. a practical religiosity, political choices are sometimes based on faith not on rational convictions.

This messianic flavor is most obvious during elections with an evident impact on people's voting behavior. This impact manifests itself at multiple levels such as the informal religious tests imposed on candidates for public office, the moralistic frame within which campaigns are conducted, and the simplistic campaign topics (abortion, school prayer, same-sex marriage, death penalty...) part of a narrow, superficial culture war. Such simplistic issues marginalize and divert people's attention away from more serious and complex topics (social disparities and polarization, violence, corruption, lobbying, neo-imperialism...).

\section{Religiosity's Impact on the Functioning of American Foreign Policy}

At the heart of the American approach to foreign affairs exists a coherent worldview, one several presidents have applied with remarkable consistency and uncompromising conviction. This view holds that the global arena can be understood as a conflict between the forces of Good and Evil, and that America is "called upon" to defend the former from the latter. By definition, this premise requires the identification of Evil, which is the enemy -an enemy that is pure in its Evil and that, by its very nature, cannot be engaged, offered compromises, negotiated with, understood, managed, contained, or ignored. It can only be hated, attacked, and destroyed.

\footnotetext{
${ }^{1}$ Emphasis added

${ }^{2}$ Alexis De Toqueville, Democracy in America (Cambridge: Sever and Francis, 1863).

${ }^{3}$ Peter Schuck and James Wilson, Understanding America (NY: PublicAffairs, 2008).

${ }^{4}$ Ibid.

${ }^{5}$ Ibid.

${ }^{6}$ Ibid.
} 
Some of the most significant presidential speeches, such as President Harry Truman's March 1947 speech, President Ronald Reagan's 1982 "Evil Empire" speech, and President George W. Bush's 2002 "Axis of Evil" speech, pictured a Manichean world of Light and Darkness, White and Black, with no shades of grey. Nazism, Communism, Terrorism, and all the "isms" on the targets list represent a demonic force candidly opposed to all that was good, true, right, and pure. With such a force, there should be no compromise, no halfway measures.

Actually, this kind of dogmatic, binary rhetoric is rooted in the nation's puritan tradition as prophetic dualism through which the world is divided into two opposite camps. Most of President George W. Bush's speeches, for instance, were filled with references to the United States being "called" or given a "mission" by the "Maker of Heaven" and "Author of Liberty." Bush's speeches have exceeded those of his predecessors in the sheer number of references to God, but there was nothing unusual in a U.S. president describing the nation's role in the world in religious terms. Many U.S. presidents have invoked the same mission - that the United States, as the "city upon a hill" and the "indispensable nation" has been called by God to achieve "the expansion of freedom in the entire world." As a matter of fact, the US has traditionally allowed religious conceptions not only to dictate ultimate goals but to color its understanding of the real world in which these goals have to be met. In 1919, Woodrow Wilson promised that through supporting the League of Nations, the United States would lead in the "redemption of the world." During World War II, Roosevelt declared in his 1942 message to Congress: "We on our side are striving to be true to [our] divine heritage".

Such notions as "world leadership", "American Mission", "America's embodiment of Good and its ideals" are often advanced to justify the Manichean dichotomy. We may identify several explicit tenets of American political ideology which have been reflected in the nation's most significant foreign policy speeches:

\section{“American Exceptionalism”}

The belief in American Exceptionalism provides an essential element of the cultural and intellectual framework for the making and conduct of U.S. foreign policy. It has always had a powerful presence in American discourse. Every president has invoked the theme of a unique America in some way or another. Consequently, a recurring theme is that foreign policy choices are made for moral reasons. At a minimum, Exceptionalism assumes that the United States is morally and culturally equipped to offer an example to the world. More proactive interpretations of Exceptionalism support the promotion of American values abroad through the use of various aspects of US power and influence.

\section{The American Mission}

One of the foundations of America's sense of its Exceptionalism is that the US has an obligation to somehow take care of the rest of the world. This paternalistic outlook has developed out of the core belief that the US is inherently more virtuous and righteous than other states. The Second World War offered a clear case for the application of America's vindicator identity in the name of international morality. President Roosevelt invoked the crusade motif in order to justify American entry into the war. America's crusade was not only in the interests of the US, it was for the good of the world. America's mission was seen as synonymous with the interests of the free world, and this fusion signaled the beginning of the monopoly of the vindicator representation that has since dominated US foreign policy.

In a 1945 speech, President Truman declared that the United States should "take the lead in running the world the way the world ought to be run." President Truman expressed America's "feeling of duty towards the civilized world". The Truman Doctrine's speech had an unmistakable "messianic" flavor: not only was the US determined to defend its own freedom, but it felt obliged to act as the defender of "freedom everywhere" throughout the world.

\section{A Sense of Moral Certitude}

Religiously-oriented leaders, by definition, believe that they are acting in pursuit or defense of the Good and against Evil. In this way, the binary dualism would have a moral function: to offer its holders a sense of moral certitude, which leaves no room for doubt or regret.

\section{War Justification}

The discourse rooted in Good and Evil legitimates any action undertaken in the name of good, no matter how destructive, on the grounds that it is attacking 'evil.' By clearly distinguishing two distinct sides to the global perspective, a binary opposition leaves no room for different interpretations. This simplistic prism

\footnotetext{
${ }^{7}$ President Truman quoted in Charles W. Kegley and Eugene R. Wittkopf, American Foreign Policy: Pattern and Process (New York: St. Martin's Press, $4^{\text {th }}$ Edition, 1991).
} 
positions the United States as the bastion of goodness and defender of righteousness in the world. Notably, such dramatic binary opposition seems likely to facilitate the assuaging of guilt associated with war.

\section{The Simplification of Complex Events, Decisions, and Acts}

Religiously-oriented discourses simplify often complex external questions in a manner which is consonant with the American approach to foreign issues, given that the ordinary American has little sustained interest in or understanding of foreign affairs. Indeed, the binary, demonizing and reductionist discourse is meant to simplify complex events in order to "sell" certain unacceptable policies to an uninformed and deeply religious audience. What makes this type of communication so important is its capacity to create a false dilemma; that is, binary constructions present a limited view of the world and, often, force a decision between two options that, in actuality, are not the only outcomes available. In this way, a Good versus Evil battle is much more likely to gain the attention and approval of the American public, since it reduces a potentially complex scenario to an easily accessible question of morality and identity.

\section{Religious Discourse as a Strategic Political Communication Device to Mobilize Public Opinion}

Political leaders can adopt the language of moralism as a tool for persuading citizens of the necessity and justifiability of certain actions. Controversial actions that, in fact, have little or nothing to do with a concern for good and evil can nonetheless be rhetorically justified via a dualistic appeal. Thus, issues can be framed in holy terms to manipulate public opinion, to cast morally neutral or even immoral policies as necessary for defense of the good, and to thereby generate support for actions they wish to undertake.

The Good vs. Evil, "We" vs. "them" approach serves dramatically to mobilize public support for a course of action deemed essential in foreign affairs. Moreover, it plays an essential role in promoting national unity on key foreign policy issues. Indeed, usage of religious codes and messages as a means to unite groups against an enemy or in favor of a policy has been a recurring strategy in American politics. Based on simple, unsophisticated, and often-misleading perceptions, the discourse rooted in Good and Evil offers a public relations device - actually a mass deception device- meant to prepare the American people psychologically for such extensive, continuing and unforeseen overseas commitments, such as the "Containment of Communism" and the "War on Terrorism". In an almost pavlovian way, the binary discourse manufactures retaliatory feelings and heats up war fever among the masses.

\section{To Marginalize Criticism and Weaken Dissent}

The binary view of good and evil comes not merely to define every significant political issue but to engulf all political debate. One is presented with a false choice: embrace and actively support the president's policies to wage war on Evil or side with evil, either deliberately or by default. Stressing morality, national unity and patriotism provides rhetorical cover for suppressing dissent, and thus threatens U.S. democracy.

\section{Belief in Moral Rightness and Lack of Flexibility and Pragmatism}

One of the principle dangers of vesting power in a leader who is convinced of his own righteousness who believes that he has been called to a crusade against evil- is that the moral imperative driving the mission will justify any and all means used to achieve it. Those who have become convinced that they are waging an epic and passionate existential war against evil cannot, by the very premises of their belief system, accept any limitations -moral, pragmatic, or otherwise- on the methods adopted to triumph in this battle.

In his book The Conservative Soul, political scientist Andrew Sullivan notes: "The essential claim of the fundamentalist is that he knows the truth. The fundamentalist doesn't guess or argue or wonder or question. He doesn't have to. He knows...". In fact, serenity flows and anxiety is eliminated by the conviction that one has found absolute truth Moral rightness trumps pragmatic success, and the imperatives of the crusade trump the constraints of reality.

Furthermore, embracing a core, unshakable conviction of one's own rightness legitimizes some of the most amoral and ethically monstrous policies, justified as necessary means to achieve a morally imperative end. Those who believe that they are on the path of righteousness, who are crusaders for the objective Good, will frequently become convinced that there can be no limitations on the weapons used to achieve their ends. The moral imperative of their agenda justifies all steps undertaken to fulfill it. Intoxicated by his own righteousness and therefore immune from doubt, the crusader becomes capable of acts of moral monstrousness that would be unthinkable in the absence of such unquestionable moral conviction. One who believes himself to be leading a supreme war against evil on behalf of good will be incapable of understanding any claims that he himself is acting immorally. A perfect example would be the $19^{\text {th }} \mathrm{c}$. genocide against indigenous Americans in the name of Manifest Destiny and Divine Ordinance.

${ }^{8}$ Andrew Sullivan, The Conservative Soul (NY: HarperCollins Publishers, 2006). 
For the inflexible believer, the battle between Good and Evil is paramount. It subordinates all other considerations and never gives way to any conflicting or inconsistent goals. Measures intended to promote Good or undermine Evil are, by definition, necessary and just. They cannot be abandoned for pragmatic or prudential reasons, or because of growing opposition, or in response to evidence of failure. In sum, complexities, pragmatic considerations, the restraints of reality are trumped by the imperative of the moral crusade.

\section{Entitlement to Power}

From the president's overarching conviction that he is on the side of Good emerges a relentless pursuit of maximum power and an accompanying sense of entitlement to that power. Indeed, when expressed and implemented as a governing philosophy, this belief in the centrality of Good vs. Evil results not in an effort to limit government power, but rather to expand it drastically, both domestically and abroad, in order to accumulate power in service of the battle against perceived Evil and to impose perceptions of Good.

\section{Conclusion}

The great and tragic irony of the religion-politics nexus is that its foundations have generated some of the most morally grotesque acts and radical departures from American values. What is "good" and what is "evil" are not determined by some preordained or intrinsic distinction. Those are designations determined only by one's conduct. America has always advanced its principles as the source of its moral credibility in the world. But once those principles are relinquished and violated, America's moral credibility and its legitimate claim to "good" cease to exist.

Now, does all this lead us to conclude that the American political practice is betraying its secular foundations? The answer can only be magnificently complex. This complexity is due to the difficulty of putting certain theoretical ideals into practice. If secularism is understood as a system characterized by the absence of an official state religion and the toleration of diverse religions, then the US is a secular nation par excellence. But if secularism would involve a "wall of separation" between public political issues and private spiritual, religious convictions, then the US is by no means secular. Probably, one way to simplify this is to put emphasis on the gap between the US Constitution's secular promises (Article VI) and the real world...

\section{References}

[1]. Campbell, Neil and Kean, Alasdair. American Culture Studies. NY: Routledge, 1997.

[2]. De Toqueville, Alexis. Democracy in America. Cambridge: Sever and Francis, 1863.

[3]. Duncan, Russell and Goddard, Joseph. Contemporary America. NY: Palgrave MaCMillan, 2005.

[4]. Mauk, David and Oakland, John. American Civilization. NY: Routledge, 1995.

[5]. Peele, Gillian. Developments in American Politics. NY: Palgrave MaCMillan, 2002.

[6]. Schuck, Peter and Wilson, James. Understanding America. NY: PublicAffairs, 2008.

[7]. Sullivan, Andrew. The Conservative Soul. NY: HarperCollins Publishers, 2006. 